\title{
AKTIVITAS ANTI INFLAMASI EKSTRAK ETANOL AGERATUM CONYZOIDES (L.) L. DAN BLUMEA BALSAMIFERA (L.) DC. DAN TOKSISITAS AKUT
}

\section{AGERATUM CONYZOIDES (L.)L. ANTIINFLAMMATORY ACTIVITY OF ETHANOL EXTRACT FROM AGERATUM CONYZOIDES (L.) L. AND BLUMEA BALSAMIFERA (L.) DC. AND ACUTE ORAL TOXICITY}

\author{
Yani Mulyani ${ }^{\star *}$, Rahma Fatwia ${ }^{2}$, Entris Sutrisno ${ }^{3}$ \\ 1,2,3 Fakultas Farmasi, Universitas Bhakti Kencana Bandung \\ Email: ${ }^{1 *}$ yani.mulyani@stfb.ac.id, ${ }^{2}$ rfatwia@gmail.com, ${ }^{3}$ entris.sutrisno@stfb.ac.id
}

\begin{abstract}
ABSTRAK
Tanaman yang digunakan secara tradisonal dalam pengobatan diantaranya daun sembung dan bandotan untuk mengobati berbagai macam penyakit, salah satunya sebagai anti inflamasi. Penelitian ini bertujuan untuk mengetahui dan membandingkan efek anti inflamasi dari ekstrak etanol tanaman bandotan (Ageratum conyzoides (L.) L.) dan daun sembung (Blumea balsamifera (L.) DC.) dengan dosis 200,300 dan $400 \mathrm{mg} / \mathrm{Kg}$ BB yang ditinjau dari penurunan volume udem telapak kaki tikus yang diinduksi karagenan. Natrium diklofenak digunakan sebagai pembanding dengan dosis $75 \mathrm{mg} / 70 \mathrm{kgBB}$. Pengukuran volume udem dilakukan setiap 30 menit selama 6 jam setelah induksi karagenan. Dari semua variasi dosis pada penelitian ini, dosis efektif yang memiliki persentase inhibisi udem paling mendekati kontrol pembanding $(90 \%)$ yaitu dosis bandotan $400 \mathrm{mg} / \mathrm{kgBB}$ yakni sebesar $78 \%$. Berdasarkan hasil analisa statistik, data persentase inhibisi udem ekstrak etanol tanaman bandotan dari dosis $400 \mathrm{mg} / \mathrm{Kg}$ BB menunjukkan perbedaan yang bermakna $(\rho \leq 0,05)$ dengan kontrol positif. Pada tanaman dengan aktivitas anti inflamasi terbaik ini kemudian dilakukan uji toksisitas, hasilnya nilai $L_{50}$ berkisar antara 5001-15000, artinya ekstrak tanaman bandotan bersifat praktis tidak toksik. Hasil tersebut menunjukkan bahwa ekstrak etanol daun bandotan memberikan efek anti inflamasi dan termasuk senyawa praktik tidak toksik.
\end{abstract}

Kata Kunci : Anti inflamasi, Bandotan, Sembung, Toksisitas akut

\begin{abstract}
Plants used in traditional medicine for the treatment include sembung and bandotan leaves to treat a wide range of diseases, one of them as an anti-inflammatory. This study aimed to determine the anti-inflammatory effect of the ethanol extract of bandotan (Ageratum conyzoides (L.) L.) and sembung leaves (Blumea balsamifera (L.) DC.) with a dose of $200,300,400 \mathrm{mg} / \mathrm{Kg}$ $\mathrm{BW}$, viewed from the decrease paw edema volume of rats carrageenan-induced. Sodium diclofenac had been given as a comparative control at a dose of $75 \mathrm{mg} / 70 \mathrm{Kg}$ BW. The paw volume was measured every half hour for six hours after injection carrageenan. Of all the variations of dose in this study, the effective dose which has the closest percentage to the comparative control (90\%) is a dose of $400 \mathrm{mg} / \mathrm{kg} \mathrm{BW}$ bandotan (78\% at six hours). Based on the result of statistical analysis, the percentage inhibition of edema of all the variations of dose ethanol extracts showed a significant difference $(\rho \leq 0,05)$ with positive control. This plant with the best anti-inflammatory activity, then carried out a toxicity test, the result is that the LD50
\end{abstract}


value ranges from 5001-15000, that means bandotan plant extract is practically non-toxic. These results indicate that the ethanol extract of the bandotan leaves has an anti-inflammatory effect and includes nontoxic practice compounds.

\section{Keywords : Antiinflammatory, Acute Toxicity, Bandotan, Sembung}

\section{PENDAHULUAN}

Tanaman telah digunakan untuk pengobatan sejak lama oleh berbagai lapisan masyarakat dunia baik negara maju maupun negara berkembang. World Health Organization (WHO), memperkirakan bahwa $80 \%$ populasi negara berkembang masih menggunakan pengobatan tradisional untuk pemeliharaan kesehatan, dan dalam praktiknya $85 \%$ menggunakan tumbuhan obat. Di Indonesia sendiri, penggunaan tumbuhan obat dalam upaya pemeliharaan kesehatan terus meningkat. Hal ini menandakan bahwa kesadaran masyarakat tentang pentingnya kembali ke alam telah semakin besar. Hal ini dibuktikan dengan tersedianya pelayanan kesehatan tradisional sebagai bagian dari pembangunan kesehatan nasional. 1,2.

Saat ini sudah ada bermacam-macam obat yang digunakan untuk mengatasi peradangan atau inflamasi. Terdiri dari anti inflamasi steroid dan non steroid. Anti inflamasi non steroid adalah obat yang paling banyak digunakan pada usia lanjut. Namun dari masing-masing golongan obat anti inflamasi masih memiliki banyak kekurangan, misalnya penggunaan obat anti inflamasi steroid dalam jangka panjang dapat menyebabkan efek samping yang cukup berat seperti tukak lambung, penekanan pertumbuhan, osteoporosis, memperberat penyakit diabetes melitus, dan lemah otot. Adapun anti inflamasi non steroid dapat menyebabkan gangguan pada saluran cerna seperti tukak lambung atau usus dan gangguan kardiovaskular. Oleh karena itu, diperlukan penelitian untuk mencari alternatif pengobatan inflamasi yang memiliki Reaksi Obat yang Tidak Diinginkan (RORD) ringan. ${ }^{3,4}$
Salah satu family tanaman obat yang ada di Indonesia adalah Asteraceae, contohnya antara lain: Ageratum conyzoides (L.) L. yang umumnya dikenal sebagai bandotan dan Blumea balsamifera (L.) DC. atau sering disebut sembung. Ageratum conyzoides (L.) L. atau bandotan digolongkan sebagai tanaman yang tidak diinginkan kehadirannya sehingga sering dimusnahkan. Namun sebagian masyarakat menggunakan tanaman ini sebagai obat tradisional untuk menyembuhkan berbagai macam penyakit. Ekstrak etanol daun bandotan diketahui memiliki efek anti inflamasi. Menurut penelitian ekstrak etanol bandotan menunjukkan efek yang signifikan dalam mengurangi edema pada tikus yang diinduksi dengan karagenan dan histamin. ${ }^{5}$

Blumea balsamifera (L.) DC. atau sembung secara tradisional di Indonesia digunakan untuk pengobatan rematik, nyeri haid, influenza, kembung, sakit tulang, diare, sariawan, asma, dan angina pectoris. Tanaman sembung juga mempunyai potensi sebagai anti cancer, hepatoprotektor, anti tirosin, anti diabetik, anti obesitas, anti aterogenik, penyembuhan luka, anti oksidan, anti perdarahan, anti arthritis, anti inflamasi, anti bakteri, anti plasmodial, dan beberapa potensi lain masih perlu banyak diteliti. ${ }^{6-9}$

Uji aktifitas anti inflamasi dari tanaman bandotan dan sembung yang tumbuh di daerah Indonesia masih perlu dikaji aktifitasnya. Hal ini mengingat kandungan dan jumlah metabolit sekunder pada tanaman sangat tergantung pada berbagai faktor lingkungan seperti cahaya, suhu, air tanah, kesuburan dan salinitas tanah. Untuk sebagian besar tanaman, perubahan faktor individu dapat mengubah isi dari metabolite sekunder. ${ }^{10,11}$ 
Uji toksisitas akut adalah tata cara tertentu yang dirancang untuk menentukan dosis letal median (LD50) suatu zat dan kemungkinan mekanisme kerja dan target organnya. LD50 didefinisikan sebagai dosis atau konsentrasi yang diberikan sekali (tunggal) atau beberapa kali dalam 24 jam dari satu zat yang secara statistik diharapkan dapat mematikan 50\% hewan coba. Berdasarkan hal tersebut, maka setelah dilakukan uji aktivitas anti inflamasi, dilakukanlah uji toksisitas akut yang diukur dengan penentuan LD50 ekstrak etanol daun bandotan (Ageratum conyzoides (L.) L.) dan daun sembung (Blumea balsamifera (L.) DC.) terhadap tikus putih jantan serta mengamati histopatologi yang terjadi pada organ hati jika ada kematian pada kelompok hewan uji. 12,13

\section{METODE PENELITIAN}

Alat dan Bahan : Alat yang digunakan pada penelitian ini adalah kandang, tempat makan dan minum tikus, serut kayu, peralatan kebersihan, neraca hewan, neraca analitik, pletismometer air raksa, alcohol swab, spuit $1 \mathrm{cc}$, alat-alat gelas, stopwatch, alumunium foil, kertas saring, rotary vacum evaporator, label dan spidol.

Bahan utama yang akan digunakan dalam penelitian ini adalah ekstrak etanol daun bandotan (Ageratum conyzoides (L.) L.) dan daun sembung (Blumea balsamifera (L.) DC.) yang diperoleh dari daerah Tasikmalaya, Jawa Barat. Determinasi tanaman diperoleh dari SITH, Institut Teknologi Bandung dengan nomor 5920/11.CO2.2/PL/2018 5919/11.CO2.2/PL/2018.

Karagenan sebagai penginduksi udem, natrium diklofenak sebagai pembanding, natrium klorida $0,9 \%$ pro injeksi, serta aquadest. Bahan untuk penapisan fitokimia meliputi dietil eter, etanol $70 \%, \mathrm{H}_{2} \mathrm{SO}_{4}, \mathrm{HCl}$, $\mathrm{FeCl}_{3}, \quad \mathrm{Mg}$, pereaksi LB (Liebermann Burchard), pereaksi mayer dan wagner, serta kloroform.
Kaji Etik :Kaji Etik Penelitian ini telah disetujui oleh Divisi Kaji Etik Fakultas Farmasi Universitas Padjajaran dengan nomor surat 916/UN6.KEP/EC/2019.

Ekstraksi sampel: Kedua simplisia masing-masing dihaluskan hingga terbentuk serbuk kering. Serbuk kering kemudian dimaserasi dengan etanol 96\% selama 3 hari. Ekstrak cair yang diperoleh diuapkan dengan alat rotary evaporator sampai diperoleh ekstrak kental di Laboratorium Farmakognosi-Fitokimia Program Studi Farmasi Fakultas Farmasi Universitas Bhakti Kencana Bandung.

\section{Uji Aktivitas Anti inflamasi Dengan} Metode Induksi Karagenan: Populasi yang digunakan pada penelitian ini adalah tikus putih jantan berjumlah kurang lebih 32 ekor. Tikus kemudian dibagi menjadi 8 kelompok, yaitu kelompok I sebagi kontrol positif yang diinduksi karagenan, kelompok II sebagai kontrol pembanding yang setelah diinduksi karagenan kemudian diberikan natrium diklofenak, kelompok III, IV dan V sebagai kelompok perlakuan $A$ yang setelah diinduksi karagenan diberikan larutan ekstrak etanol daun bandotan dengan dosis yang berbeda. Terakhir, kelompok VI, VII dan VIII sebagai kelompok perlakuan $B$ yang setelah diinduksi karagenan diberikan larutan ekstrak etanol daun sembung dengan dosis yang berbeda juga. Masing-masing hewan ditimbang dan diberi tanda pada ekor. Kemudian diukur volume kaki kiri tikus dengan menggunakan Pletismometer.

Data yang diperoleh dicatat sebagai volume dan diameter awal (Vo) yaitu volume kaki sebelum diberi obat dan diinduksi dengan larutan karagenan. Masing-masing tikus diberi suspensi bahan uji secara oral sesuai dengan kelompoknya. Satu jam kemudian kepada masing-masing kelompok perlakuan diinduksi secara intraplantar dengan $0,2 \mathrm{ml}$ larutan karagenan $1 \%$, setelah 30 menit dilakukan pengukuran dengan pletismometer. Dicatat volume $(\mathrm{Vt})$ sebagai volume setelah diberi obat dan diinduksi dengan larutan karagenan. 
Pengukuran dilakukan setiap 30 menit selama 360 menit.

$$
\% \text { Udem }=\frac{\text { Vt-Vo }}{V_{0}} \times 100 \%
$$

Persentase Inhibisi udem dinilai dari persentase udem pada kelompok kontrol positif (a) dan persentase udem pada kelompok uji (b)

$$
\% \text { Inhibisi udem }=\underline{a-b} \times 100 \%
$$

a

Uji toksisitas akut :Pada tanaman yang memiliki aktivitas anti inflamasi terbaik menggunakan metode yang mengacu kepada OECD 420. Tikus dibagi menjadi 4 kelompok uji sebagai berikut: Pertama kelompok I sebagai kontrol yang hanya diberikan larutan $\mathrm{Na}-\mathrm{CMC}$ secara oral, kelompok II, III dan IV sebagai kelompok perlakuan yang diberikan larutan ekstrak etanol daun yang memiliki aktivitas anti inflamasi terbaik dengan dosis 5 sampai $8000 \mathrm{mg} / \mathrm{Kg}$. Pengamatan yang dilakukan pada uji toksisitas ini meliputi pengamatan perilaku hewan uji terhadap gejala toksik selama 4 jam setelah pemberian ekstrak, kemudian setelah 24 jam diamati dan dihitung jumlah hewan uji yang mati di setiap kelompoknya. Selanjutnya, organ hati pada kelompok hewan uji yang mati dan kelompok kontrol, dibandingkan dengan cara mengamati organ tersebut secara histopatologi. Bila tidak terjadi kematian pada seluruh kelompok hewan uji, makadilakukan pengamatan berat badan selama 14 hari 13,14

Skrining fitokimia: Ekstrak daun bandotan dan daun sembung yang telah diperoleh diuji kualitatif terhadap adanya senyawa steroid ,flavonoid, fenolik, saponin, terpenoid, alkaloid, dan tanin di Laboratorium Farmakognosi-Fitokimia Program Studi Farmasi Fakultas Farmasi Universitas Bhakti Kencana Bandung.

\section{HASIL DAN PEMBAHASAN}

Hasil ekstraksi

Hasil rendemen yang diperoleh dari proses ekstraksi sebesar 9,43\% untuk daun bandotan dan $8,20 \%$ untuk daun sembung.

Tabel 1. Hasil Penapisan Fitokimia Ekstrak dan Simplisia

\begin{tabular}{ccccc}
\hline \multirow{2}{*}{$\begin{array}{c}\text { Golongan } \\
\text { Senyawa }\end{array}$} & \multicolumn{5}{c}{ Hasil Penapisan } \\
\cline { 2 - 5 } & \multicolumn{3}{c}{ Bandotan } & \multicolumn{2}{c}{ Sembung } \\
\cline { 2 - 5 } & Ekstrak & Simplisia & Ekstrak & Simplisia \\
\hline Alkaloid & + & + & + & + \\
\hline Flavonoid & + & + & + & + \\
\hline Tanin & + & + & + & + \\
\hline Saponin & - & - & + & + \\
\hline Steroid & - & - & - & - \\
\hline Kuinon & + & + & + & +
\end{tabular}

Berdasarkan hasil uji penapisan fitokimia yang dilakukan, kedua tanaman dinyatakan positif mengandung alkaloid, flavonoid, tannin dan kuinon, sedangkan negatif terhadap steroid. Kandungan saponin terdapat pada sembung. Senyawa aktif yang terdapat dalam tumbuhan umumnya dalam bentuk metabolit sekunder seperti alkaloid, flavonoid, tannin dan kuinon mempunyai aktifitas beragam, diantaranya mempunyai efek sebagai anti virus, anti kanker, anti inflamasi, anti oksidan, anti hepatoksik, dan anti diabetes. ${ }^{15-18}$.

Kandungan metabolit sekunder senyawasenyawa tanaman sembung dan bandotan yang diduga berperan dalam memberikan khasiat dan efek biologis adalah flavonoid dan saponin ${ }^{19,20}$.

\footnotetext{
Pengukuran aktivitas anti inflamasi dengan metode induksi karagenan

Proses inflamasi dapat diukur dari besarnya volume udem (menggunakan pletismometer) kaki tikus. Pengukuran dilakukan sebelum induksi dengan karagenan $1 \%$ sampai 360 menit setelah perlakuan.
} 


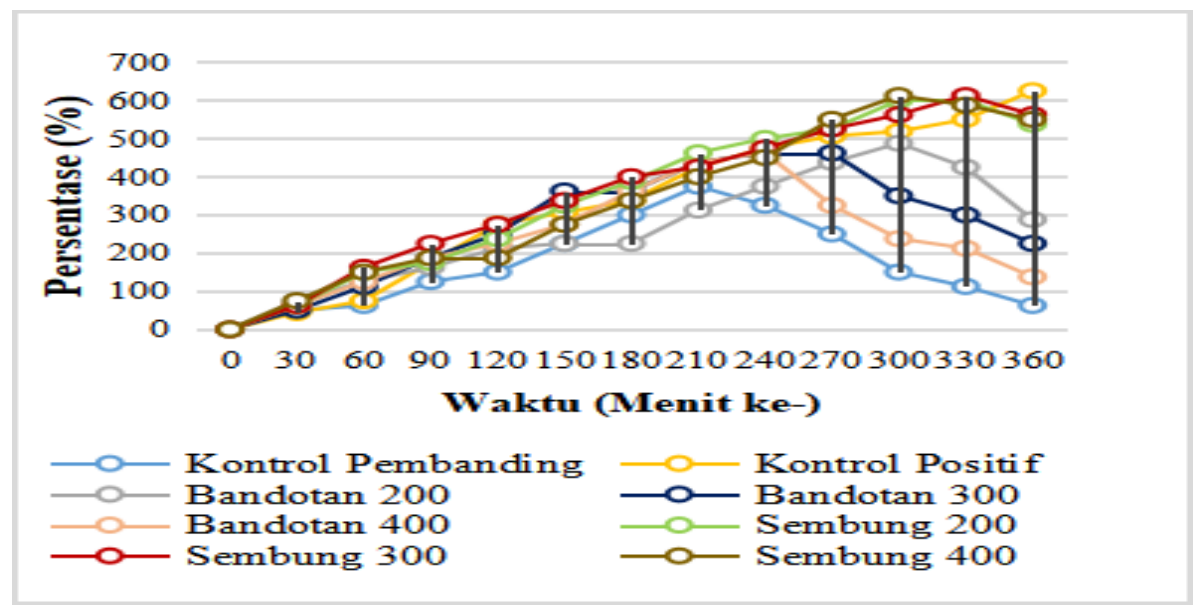

Gambar 1. Grafik rata-rata persen udem

Berdasarkan hasil penelitian ini terlihat bahwa pada semua dosis kelompok tanaman uji menunjukkan adanya efek anti inflamasi dimana persen udem rata-rata setiap kelompok zat uji tidak sebesar persen udem pada kelompok kontrol positif. Pada kelompok kontrol pembanding yang diinduksi kemudian diberi $\mathrm{Na}-\mathrm{CMC}$, persen udem terus meningkat mulai dari menit ke 30 sampai menit ke 360 dan udem maksimal.

Edema yang diinduksi karagenan melibatkan sintesis atau pelepasan mediator di lokasi yang terluka. Mediator ini termasuk prostaglandin, terutama seri E, histamin, bradikinin, leukotrien, dan serotonin, yang semuanya juga menyebabkan rasa sakit dan demam. Edema yang diinduksi karagenan adalah salah satu tes paling populer yang digunakan dalam skrining aktivitas anti inflamasi ${ }^{21}$. Induksi dengan caragenan adalah tes yang sangat sensitif dan dapat dijadikan model yang valid untuk mempelajari obat anti inflamasi baru 22. Inflamasi yang diinduksi karagenan berguna dalam mendeteksi senyawa anti inflamasi yang aktif secara oral; oleh karena itu uji ini memiliki nilai prediktif yang signifikan untuk anti inflamasi melalui mekanisme pembentukan mediator peradangan akut ${ }^{23}$. Perkembangan edema yang disebabkan oleh injeksi karagenan menyebabkan respons inflamasi akut dan lokal. Pada fase awal (0-1 jam), histamin, serotonin, dan bradikinin adalah mediator pertama yang terlibat, sedangkan prostaglandin dan berbagai sitokin seperti IL-1 $\beta$, IL-6, IL-10, dan TNF- $\alpha$ terlibat dalam fase kedua. ${ }^{24}$

Aktivitas anti inflamasi ekstrak diperkirakan karena adanya senyawa golongan alkaloid , flavonoid saponin dan tannin. Beberapa penelitian menunjukkan bahwa alkaloid menekan antigen dan proliferasi limfosit yang di induksi mitogen, sitotoksisitas sel Killer alami, pelepasan histamin oleh sel mast, sekresi interleukin-1 (IL-1) oleh monosit manusia dan aksi PAF pada platelet ${ }^{25}$. Mekanisme flavonoid dalam menghambat proses terjadinya inflamasi melalui dua cara yaitu pada fase inflamasi proliferatif maupun eksudatif ${ }^{26}$ Sedangkan mekanisme anti inflamasi saponin dari berbagai cara seperti hambatan aktivitas kortikomimetik tidak langsung dan langsung, penghambatan degradasi glukokortikoid, penghambatan pembentukan enzimatik dan pelepasan mediator inflamasi ${ }^{27}$. Selain flavonoid, tannin juga mempunyai aktivitas anti inflamasi, namun mekanisme kerjanya sebagai anti inflamasi belum dijelaskan secara pasti ${ }^{28}$. 


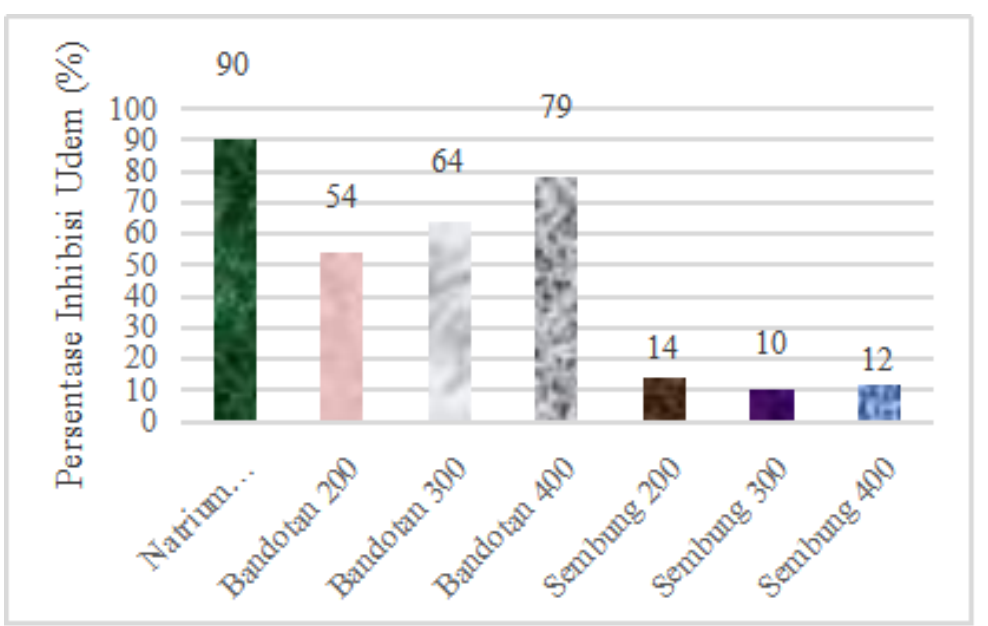

Gambar 2. Grafik persen inhibisi udem pada menit ke-360

Udem tertinggi terdapat pada menit ke 210 dan mulai mengalami penurunan 30 menit setelahnya sampai kaki hampir kembali ke ukuran normal pada menit ke 360. Pada seluruh kelompok tanaman uji terdapat inhibisi pembentukan udem pada setiap 30 menit.

Tabel 2. Persentase radang dan persentase hambatan rata-rata \pm SD pada menit ke-360

\begin{tabular}{|c|c|c|}
\hline Kelompok & $\begin{array}{c}\text { Persentas } \\
\text { e } \\
\text { Radang } \\
(\%) \pm \text { SD }\end{array}$ & $\begin{array}{c}\text { Persentas } \\
\text { e } \\
\text { Hambatan } \\
(\%) \pm \text { SD }\end{array}$ \\
\hline $\begin{array}{c}\text { Kontrol } \\
\text { Positif }\end{array}$ & $\begin{array}{c}625,00 \pm \\
1,60^{*}\end{array}$ & $\begin{array}{c}0,00 \pm \\
0,00^{*}\end{array}$ \\
\hline $\begin{array}{c}\text { Pembandin } \\
\mathrm{g}\end{array}$ & $\begin{array}{c}62,50 \pm \\
0,22\end{array}$ & $\begin{array}{c}90,00 \pm \\
0,04\end{array}$ \\
\hline $\begin{array}{l}\mathrm{BN} 200 \\
\mathrm{mg} / \mathrm{Kg}\end{array}$ & $\begin{array}{c}287,50 \pm \\
0,41^{*}\end{array}$ & $\begin{array}{c}54,00 \pm \\
0,14^{*}\end{array}$ \\
\hline $\begin{array}{l}\mathrm{BN} 300 \\
\mathrm{mg} / \mathrm{Kg}\end{array}$ & $\begin{array}{c}225,00 \pm \\
0,75 @\end{array}$ & $\begin{array}{c}64,00 \pm \\
0,15^{@}\end{array}$ \\
\hline $\begin{array}{l}\mathrm{BN} 400 \\
\mathrm{mg} / \mathrm{Kg}\end{array}$ & $\begin{array}{c}137,50 \pm \\
0,41 @\end{array}$ & $\begin{array}{c}78,00 \pm \\
0,06 @\end{array}$ \\
\hline $\begin{array}{l}\mathrm{SM} 200 \\
\mathrm{mg} / \mathrm{Kg}\end{array}$ & $\begin{array}{c}537,50 \pm \\
0,41^{*}\end{array}$ & $\begin{array}{c}14,00 \pm \\
0,43^{*}\end{array}$ \\
\hline $\begin{array}{l}\mathrm{SM} 300 \\
\mathrm{mg} / \mathrm{Kg}\end{array}$ & $\begin{array}{c}562,50 \pm \\
0,42^{*}\end{array}$ & $\begin{array}{c}10,00 \pm \\
0,41^{*}\end{array}$ \\
\hline $\begin{array}{l}\mathrm{SM} 400 \\
\mathrm{mg} / \mathrm{Kg}\end{array}$ & $\begin{array}{c}550,00 \pm \\
0,61^{*}\end{array}$ & $\begin{array}{c}12,00 \pm \\
0,36^{*}\end{array}$ \\
\hline
\end{tabular}

Keterangan:

Persentase yang diambil pada menit ke-360

BN: Ekstrak tanaman bandotan ; SM:

Ekstrak daun sembung

* Berbeda bermakna dengan kelompok pembanding

@ Tidak berbeda bermakna dengan kelompok pembanding

Tabel 2. dan gambar 2. bisa dilihat bahwa persentase inhibisi pembentukan udem pada kelompok uji tanaman bandotan jauh lebih tinggi dari kelompok uji tanaman sembung, terutama pada kelompok dosis $400 \mathrm{mg} / \mathrm{KgBB}$, hambatan yang terjadi paling mendekati kelompok kontrol pembanding, yaitu sebesar $79 \%$. Hal tersebut menandakan bahwa pemberian ekstrak bandotan dengan dosis sebesar $400 \mathrm{mg} / \mathrm{kgBB}$ merupakan dosis yang berpotensi tinggi dalam menghambat udem, karena terlihat dari persentase penghambatan terbesar. Hal ini dapat diartikan bahwa dosis $400 \mathrm{mg} / \mathrm{kgBB}$ merupakan dosis yang paling efektif jika dibandingkan dengan dosis lainnya (200, $300 \mathrm{mg} / \mathrm{kgBB}$ ).

Hasil yang diperoleh dari persentase inhibisi udem selanjutnya dianalisis dengan uji ANOVA untuk melihat bermakna atau tidak perbedaan dari masing- masing kelompok. Dalam uji ANOVA ini harus memenuhi persyaratan seperti syarat normalitas dan homogenitas data. Karena 
syarat ANOVA tidak terpenuhi maka dilanjutkan dengan uji Kruskal Wallis, dilanjutkan dengan uji BNT (Beda Nyata Terkecil) dengan metode LSD untuk melihat perbedaan antar kelompok perlakuan bermakna $(\rho \leq 0,05)$ atau tidak bermakna $(\rho \geq 0,05)$. Berdasarkan hasil uji LSD menunjukkan ekstrak bandotan dosis $200 \mathrm{mg} / \mathrm{kgBB}, 300 \mathrm{mg} / \mathrm{kgBB}$ dan 400 $\mathrm{mg} / \mathrm{kgBB}$ memiliki perbedaan yang bermakna dengan kontrol positif $(\rho \leq 0,05)$ namun tidak berbeda bermakna dengan kontrol pembanding $(\rho \geq 0,05)$. Sedangkan ekstrak sembung telah menunjukkan perbedaan tidak bermakna sejak menit ke 30. Hal ini menunjukkan bahwa ekstrak bandotan dosis $200 \mathrm{mg} / \mathrm{kgBB}, 300$ $\mathrm{mg} / \mathrm{kgBB}$ dan $400 \mathrm{mg} / \mathrm{kgBB}$ berpotensi mengurangi volume udem dan kemampuan menghambat udem pada telapak kaki tikus sama dengan kontrol pembanding. Ekstrak bandotan dosis $200 \mathrm{mg} / \mathrm{kgBB}$ kemudian menunjukkan perbedaan yang bermakna dengan kontrol pembanding pada menit ke 300. Hal ini menunjukkan bahwa ekstrak bandotan dosis 300 dan $400 \mathrm{mg} / \mathrm{kgBB}$ memiliki kemampuan menghambat udem yang lebih baik dibanding ekstrak bandotan dosis $200 \mathrm{mg} / \mathrm{kgBB}$.

Efek anti inflamasi dapat dilihat dari kandungan yang terdapat pada ekstrak bandotan dan sembung yaitu, senyawa golongan alkaloid, flavonoid, saponin dan tanin yang telah diketahui memiliki efek anti inflamasi.

Flavonoid memiliki efek anti inflamasi melalui mekanisme penghambatan aktivitas enzim siklooksigenase atau lipooksigenase secara langsung sehingga menyebabkan penghambatan biosintesis eikosanoid dan leukotrin ${ }^{29}$.

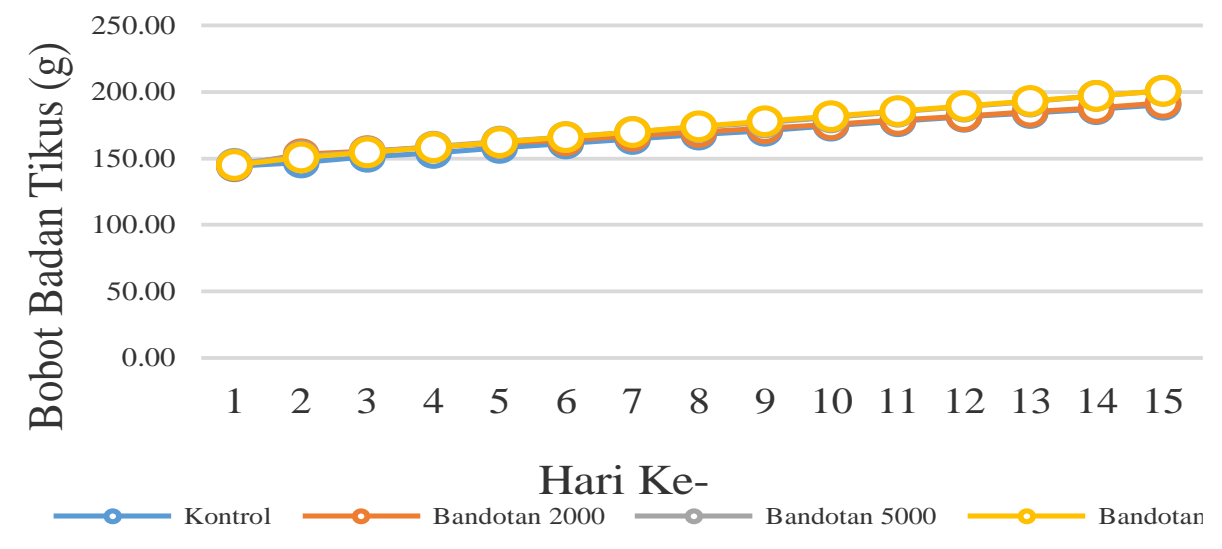

Gambar 2. Grafik Bobot Badan hari ke 1-15

\section{Pengukuran toksisitas akut dengan metode OECD 420}

Uji toksisitas akut dalam penelitian ini bertujuan untuk menilai keamanan ekstrak etanol tanaman bandotan apabila digunakan dalam jumlah dosis yang besar serta menetapkan potensi ketoksikan dari ekstrak tersebut. Pengamatan dilakukan selama 4 jam setelah pemberian dosis uji, hasilnya semua hewan uji pada masing- masing kelompok perlakuan tidak mengalami kematian serta menunjukkan adanya gejala dan tanda klinik keracunan. Aktivitas motorik pun terpantau baik bahkan setelah 24 jam. Oleh karena itu, pengamatan dilanjutkan dengan pengukuran bobot hewan uji selama 14 hari. 
Berdasarkan hasil pengamatan selama 14 hari, masih belum ditemukan kematian, penurunan aktivitas motorik serta gejala toksik lainnya. Kesehatan dan nafsu makan hewan uji pun tidak terganggu.

Dari Gambar 2 dapat disimpulkan dari pertumbuhan berat badan hewan uji selama 14 hari semua tikus pada masingmasing kelompok perlakuan rata-rata mengalami peningkatan berat badan yang signifikan. Setelah membandingkan tabel potensi Toksisitas Menurut PPRI No. 74 Tahun 2001 dengan data yang didapatkan peneliti, dapat disimpulkan bahwa ekstrak etanol bandotan termasuk ke dalam kategori praktis tidak toksik sehingga penggunaannya secara oral cukup aman.

Tabel 3. Hasil Pengamatan Jumlah Kematian, Gejala dan Tanda-Tanda Toksisitas Hewan Uji

\begin{tabular}{llc}
\hline $\begin{array}{l}\text { Kelompok } \\
\text { Perlakuan }\end{array}$ & $\begin{array}{c}\text { Jumlah } \\
\text { Kematian }\end{array}$ & $\begin{array}{c}\text { Gejala dan } \\
\text { Tanda-Tanda } \\
\text { Toksisitas }\end{array}$ \\
\hline Kontrol & Tidak ada & $\begin{array}{c}\text { Tidak } \\
\text { ditemukan }\end{array}$ \\
\hline $\begin{array}{l}\text { Bandotan } \\
\mathbf{2 0 0}\end{array}$ & Tidak ada & $\begin{array}{c}\text { Tidak } \\
\text { ditemukan }\end{array}$ \\
\hline $\begin{array}{l}\text { Bandotan } \\
\mathbf{3 0 0}\end{array}$ & Tidak ada & $\begin{array}{c}\text { Tidak } \\
\text { ditemukan }\end{array}$ \\
\hline $\begin{array}{l}\text { Bandotan } \\
\mathbf{4 0 0}\end{array}$ & Tidak ada & $\begin{array}{c}\text { Tidak } \\
\text { ditemukan }\end{array}$ \\
\hline
\end{tabular}

\section{SIMPULAN}

Ekstrak etanol tanaman bandotan (Ageratum conyzoides (L.) L.) dan daun sembung (Blumea balsamifera (L.) DC.) memiliki aktivitas anti inflamasi dimana ekstrak etanol tanaman bandotan dengan dosis $400 \mathrm{mg} / \mathrm{Kg}$ BB memiliki aktivitas anti inflamasi paling baik dengan persentase inhibisi udem sebesar $78 \%$.

Ekstrak etanol daun bandotan (Ageratum conyzoides (L.) L.) termasuk ke dalam kategori praktis tidak toksik. Penggunaan secara oral aman dst disampaikan

\section{DAFTAR PUSTAKA}

1. Kemenkes RI. Kemenkes RI. Profil Kesehatan Indonesia 2017. Data dan Informasi. Kementrian Keseahtan RI; 2018. Jurnal IImu Kesehatan. 2018.

2. WHO. Review of Traditional Medicine in the South-East Asia Region. WHO. 2005.

3. Harifforoosh S, Asghar W, Jamali F. Adverse effects of nonsteroidal antiinflammatory drugs: an update of gastrointestinal, cardiovascular and renal complications. J Pharm Pharm Sci [Internet]. 2013 [cited 2019 Sep 24];16(5):821-47. Available from: http://www.ncbi.nlm.nih.gov/pubmed /24393558

4. Wongrakpanich S, Wongrakpanich A, Melhado K, Rangaswami J. A Comprehensive Review of NonSteroidal Anti-Inflammatory Drug Use in The Elderly. Aging Dis [Internet]. 2018 Feb [cited 2019 Sep 20];9(1):143-50. Available from: http://www.ncbi.nlm.nih.gov/pubmed /29392089

5. Hassan M, Shahid-Ud-Daula AFM, Jahan IA, Nimmi I, Adnan T, Abdullah-Al-Mansur, et al. Antiinflammatory activity, total flavonoids and tannin content from the ethanolic extract of Ageratum conyzoides Linn. leaf. J Pharm Phytopharm Res. 2012;1(5):234-41.

6. Pang $Y$, Wang $D$, Fan $Z$, Chen $X$, $\mathrm{Yu} F$, $\mathrm{Hu} X$, et al. Blumea balsamifera-A Phytochemical and Pharmacological Review. Molecules [Internet]. 2014 Jul 3 [cited 2019 Sep 24];19(7):9453-77. Available from:

http://www.ncbi.nlm.nih.gov/pubmed 124995927

7. Pang $\mathrm{Y}$, Zhang $\mathrm{Y}$, Huang $\mathrm{L}, \mathrm{Xu} \mathrm{L}$, Wang $K$, Wang $D$, et al. Effects and mechanisms of total flavonoids from Blumea balsamifera (L.) DC. on skin wound in rats. Int $\mathrm{J}$ Mol Sci [Internet]. 2017 Dec 19 [cited 2019 Sep 24];18(12). Available from: http://www.ncbi.nlm.nih.gov/pubmed 


\section{/29257119}

8. Dalimartha S. Atlas tumbuhan obat Indonesia [Internet]. Pustaka Bunda; 2008. (Atlas tumbuhan obat Indonesia: menguak kekayaan tumbuhan obat Indonesia). Available from:

https://books.google.co.id/books?id= -1TuYu 7ehoC

9. Rahardjo SS. Review Tanaman Sembung [Blumea balsamifera (L.)]. Proceeding Mulawarman Pharm Conf. 2016 Apr 26;3:18-28.

10. Yang L, Wen K-S, Ruan X, Zhao Y$X$, Wei $F$, Wang $Q$. Response of Plant Secondary Metabolites to Environmental Factors. Molecules [Internet]. 2018 Mar 27 [cited 2019 Sep 24];23(4). Available from: http://www.ncbi.nlm.nih.gov/pubmed /29584636

11. Zhao DF, Buchholz A, Tillmann R, Kleist E, Wu C, Rubach F, et al. Environmental conditions regulate the impact of plants on cloud formation. Nat Commun [Internet]. 2017 Apr 20 [cited 2019 Sep 24];8(1):14067. Available from: http://www.nature.com/articles/ncom ms14067

12. Sasmito WA, Wijayanti AD, Fitriana I, Sari PW. Pengujian Toksisitas Akut Obat Herbal Pada Mencit Berdasarkan Organization for Economic Co-operation and Development (OECD). J Sain Vet. 2017 Jan 19;33(2).

13. Badan Pengawas Obat dan Makanan RI. Peraturan Kepala Badan Pengawas Obata dan Makanan Republik Indonesia. Bpom Ri 2014 p. 1-16.

14. Sasmito WA, Wijayanti AD, Fitriana I, Sari PW. Pengujian Toksisitas Akut Obat Herbal Pada Mencit Berdasarkan Organization for Economic Co-operation and Development (OECD). J Sain Vet [Internet]. 2017 Jan 19 [cited 2019 Sep 20];33(2). Available from: https://jurnal.ugm.ac.id/jsv/article/vie w/17924

15. Bribi N. Pharmacological activity of
Alkaloids: A Review. Asian J Bot. 2018;1(April):1-6.

16. Chung K-T, Wong TY, Wei C-I, Huang $Y-W$, Lin $Y$. Tannins and Human Health: A Review. Crit Rev Food Sci Nutr [Internet]. 1998 Aug [cited 2019 Sep 20];38(6):421-64. Available from: http://www.ncbi.nlm.nih.gov/pubmed /9759559

17. Ghasemzadeh A, Ghasemzadeh N. Flavonoids and phenolic acids: Role and biochemical activity in plants and human. Vol. 5, Journal of Medicinal Plant Research. 2011. p. 6697-703.

18. Martínez MJA, Benito PB. Biological Activity of Quinones. Stud Nat Prod Chem [Internet]. 2005 Jan 1 [cited 2019 Sep 20];30:303-66. Available from:

https://www.sciencedirect.com/scien ce/article/pii/S1572599505800365

19. Hidayati NA. Kandungan kimia dan uji antiinflamasi ekstrak etanol lantana camara I. pada tikus putih (rattus norvegicus I.) jantan. 2006 [cited 2019 Sep 20]; Available from: https://digilib.uns.ac.id/dokumen/det ail/6294/Kandungan-kimia-dan-ujiantiinflamasi-ekstrak-etanol-lantanacamara-I-pada-tikus-putih-rattusnorvegicus-I-jantan

20. Fitriyani $A$, Winarti $L$, Muslichah $S$, Nuri. UJI ANTIINFLAMASI EKSTRAK METANOL DAUN SIRIH MERAH ( Piper. Maj Obat Tradis. 2011;16(1):34-42.

21. WinterE.A, Risley E, Nuss G. Carragenin induced oedema in hind paw of the rats as an assay of antiinflammatory drugs. In: Proceedings of the Society for Experimental Biology and Medicine. 1962. p. 5447.

22. Willoughby DA, DiRosa M. Studies on the mode of action of non-steroid anti-inflammatory drugs. Ann Rheum Dis [Internet]. 1972 Nov 1 [cited 2019 Sep 20];31(6):540-540. Available from: http://www.ncbi.nlm.nih.gov/pubmed 14634774 
23. Vinegar R, Schreiber W, Hugo R. Biphasic development of carrageenin edema in rats. $\mathrm{J}$ Pharmacol Exp Ther [Internet]. 1969 Mar [cited 2019 Sep 20];166(1):96103. Available from: http://www.ncbi.nlm.nih.gov/pubmed /5776026

24. Crunkhorn P, Meacock SC. Mediators of the inflammation induced in the rat paw by carrageenin. $\mathrm{Br} J$ Pharmacol [Internet]. 1971 Jul [cited 2019 Sep 20];42(3):392-402. Available from: http://www.ncbi.nlm.nih.gov/pubmed 14104654

25. Barbosa-Filho JM, Piuvezam MR, Moura MD, Silva MS, Lima KVB, daCunha EVL, et al. Anti-inflammatory activity of alkaloids: a twenty-century review. Rev Bras Farmacogn [Internet]. 2006 Mar [cited 2019 Sep 30];16(1):109-39. Available from: http://www.scielo.br/scielo.php?scrip $\mathrm{t}=\mathrm{sci}$ arttext\&pid=S0102695X2006000100020\&lng=en\&nrm= iso\&tlng $=$ en

26. Rathee $\mathrm{P}$, Chaudhary $\mathrm{H}$, Rathee $\mathrm{S}$, Rathee D, Kumar V, Kohli K. Mechanism of action of flavonoids as anti-inflammatory agents: A review. Inflamm Allergy - Drug Targets. 2009;8(3):229-35.

27. Mohammed MS, Osman WJA, Garelnabi EAE, Osman Z, Osman $B$, Khalid HS, et al. Secondary metabolites as anti-inflammatory agents. J Phytopharm [Internet]. 2014;3(4):275-85. Available from: www.phytopharmajournal.com

28. Khanbabaee K, van Ree T. Tannins: Classification and definition. Nat Prod Rep. 2001;18(6):641-9.

29. Cody V, Middleton E, Harborne JB, Beretz A. Plant Flavonoids in Biology and Medicine II: Biochemical, Cellular, and Medicinal Properties (Progress in Clinical and Biological Research). Cody V, Middleton E, Harborne JB, Beretz A, editors. Wiley-Liss; 1988. 